\title{
DAM FAILURE EFFECTS ON LOCAL/REGIONAL CRITICAL INFRASTRUCTURES
}

\begin{abstract}
Marius-Eugen PÎRVULEȚU - Specialist in the Ministry of Internal Affairs, e-mail: marius.eugen.86@gmail.com. Aurelian Florentin DRĂGHIA - Researcher at the Technical University of Civil Engineering Bucharest
\end{abstract}

\begin{abstract}
Summary: The paper will focus on multi-hazard assessment following the failure of the Ezer dam on Jijia river. All induced risks are analyzed in terms of critical infrastructure protection, considering three possible failure scenarios.

The challenge of these scenarios is to consider the possible effects (continue effects, domino effect, cascading effects) induced by a single hazard, but which may cause one or more sequential hazards. In all three possible failure scenarios it was considered that the bottom gates are not operational, being blocked. The upper boundary condition in the model is the flood with the maximum discharge $0.1 \%$. This area chosen for analysis is economically underdeveloped. The protective measures are quite low and the exposure generated by accidents at the hydraulic structures or by the extreme weather conditions is quite high either for the existing economic context or for the future investments in those areas.

The implementation by the decision makers of measures for reducing the risk or the multiple risks cannot be done at regional level if all the vulnerabilities in the area are not widely known.
\end{abstract}

Keywords: critical infrastructure, failure scenario, multi-risk analysis, vulnerability.

\section{Introduction}

Throughout history, the floods have had a prominent role on humanity, producing impressive property damage and loss of life. About their destructive character, there are still notes from the XVIth century when floods have occurred with a very high degree of severity [1].

The national strategies in the field put a lot of emphasis on this type of threat, and in Romania so far a number of infrastructures that provide important services to society have been affected by this phenomenon [6].

The problem of floods was a major topic of discussion for the entire international community. The subjects discussed in various thematic groups, workshops, etc. targeted the following purposes [4]:

- highlighting the difficulties arising from the old management floods practices;

- $\quad$ assessing the current situation of the studies in the field;

- identifying the best current practices;

- establishing specific arrangements for the supply of scientific information generated from research to users and decision makers;

- developing research directions in the future.

At national level, until now a unitary framework for multi-risk assessment caused by a dam failure and the effect on other critical infrastructure does not exist yet.

This paper is a starting point for multi-risk assessment induced by dams' failure at the river basin level and inserting it into a regional/national communications and early warning mechanism on critical infrastructures protection. 
The original hydraulic model of the study area, including the model set-up and its calibration/validation, was developed in the frame of the National Programme on Flood Prevention, Protection and Mitigation in the period 2011-2013 at the level of the whole country.

\section{Dam failure scenarios - a case study on the Ezer dam failure}

In the following, three failure scenarios at the Ezer dam will be presented. The water level in the lake corresponds to the verification level for $\mathrm{Q} 0.1 \%=154.72 \mathrm{mdMN}$. The upper boundary condition in the model is the flood with the maximum discharge $0.1 \%$. In all three scenarios it was considered that the bottom gates are not working.

\subsection{Failure scenario No. 1 - failure of the earth dam}

In the first scenario it was considered that the failure begins by erosion: during the first 60 minutes the flow takes place under pressure through an orifice whose radius grows up to $1 \mathrm{~m}$ when collapse occurs, and the flow becomes free level.

The breach hydrograph was obtained using the Dambreak module of Mike 11 software.

The capacity curve of the lake is presented in Figure 1:

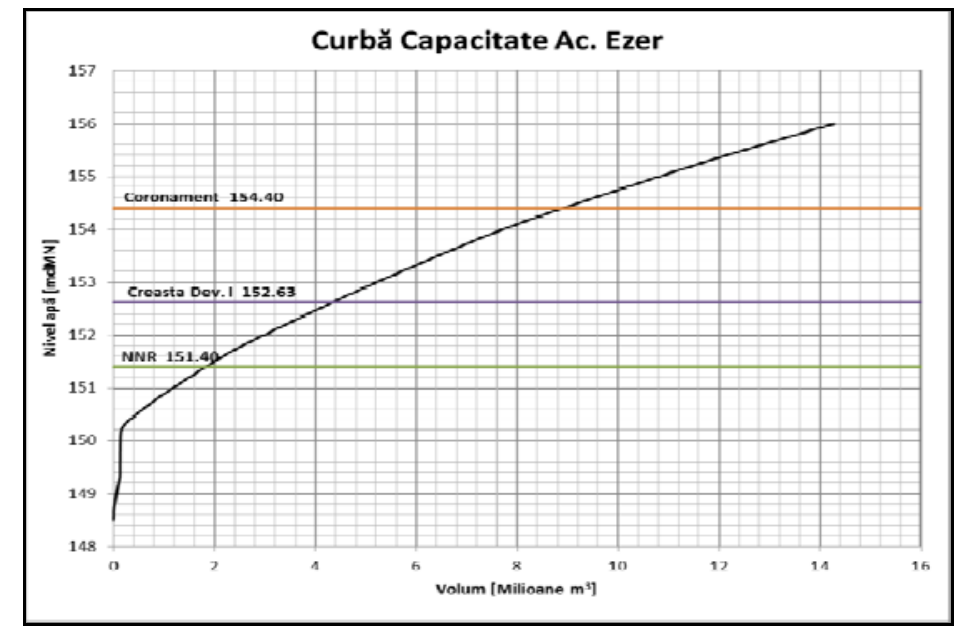

Fig. 1 - Capacity curve of Ezer reservoir

To choose the worst section where the failure could occur, 11 cross sections in the earth dam were analysed.

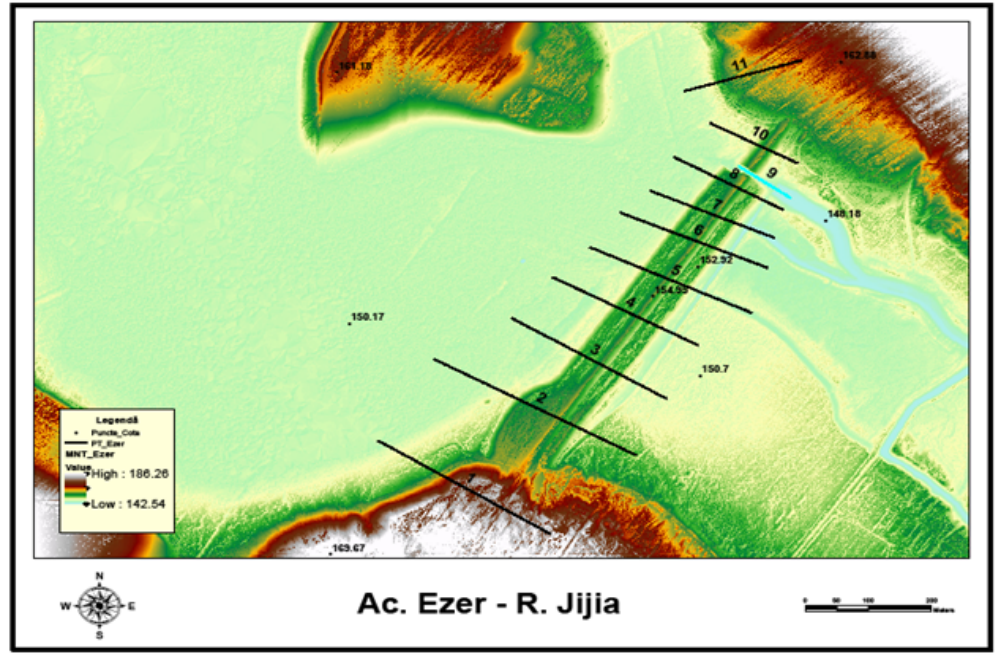

Fig. 2 - The position of the cross sections through the earth dam 
The worst situation corresponds to Section 7, for which release calculations were performed. The discharge hydrograph resulted in scenario 1 is presented in Figure 3, and it has a maximum flow of about $280 \mathrm{~m} 3 / \mathrm{s}$.

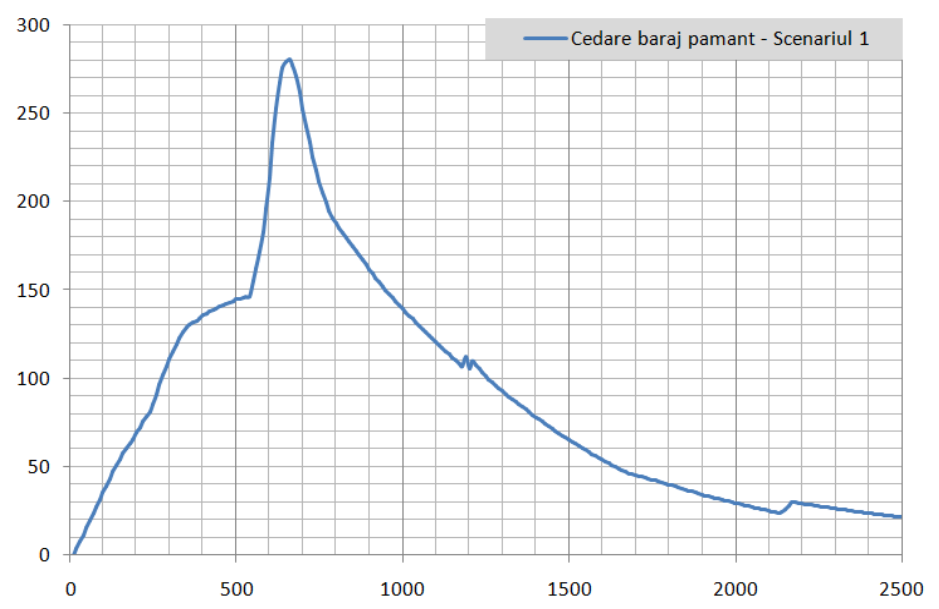

Fig. 3 - Flow hydrograph resulting from earth dam failure

\subsection{Scenario no. 2 - concrete dam failure, hypothesis 1 - the sliding of the monolithic block of the spillway}

The S2 scenario consists in the sliding of the monolithic block of the concrete spillway, accompanied by the development of a breach in the earth dam at the contact with the concrete dam having a maximum opening of $16 \mathrm{~m}$ at the dam crest level (155.25 MaSL).

The breaking is initiated by the flood $0.1 \%$, the bottom gates being blocked in closed position; the development of the sliding begins when due to the flood retention in the reservoir, the water level reaches the crest.

The hypotheses that characterize this scenario are:

- the water level in Ezer reservoir corresponding to Q $0.1 \%$ is $154.72 \mathrm{MaSL}$, while the crest elevation is $155.25 \mathrm{MaSL}$;

- the concrete dam failure occurs by sliding over a period of 3 hours;

- the breach development in the earth dam occurs in 3 hours; the breach slope is 1:2.

It should be noted that in the discharge calculation through the breach area, the water level decrease from the reservoir with respect to time was taken into account. The breach hydrograph was obtained using the Dambreak module of Mike 11 software.

The discharge hydrograph resulted in scenario 2 is presented in Figure 4, and the flow has a maximum value of about $569 \mathrm{~m} 3 / \mathrm{s}$.

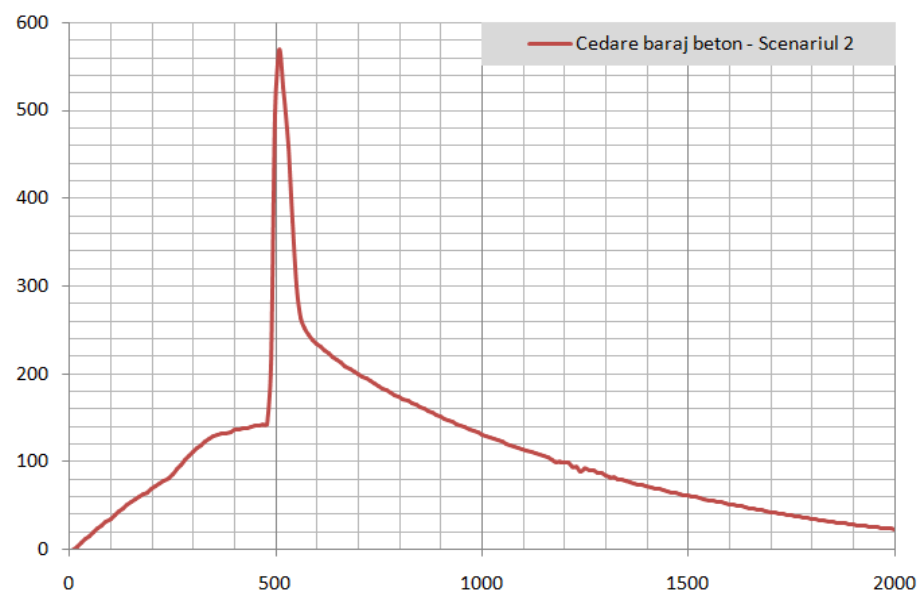

Fig. 4 - Flow hydrograph resulting from concrete dam failure - hypothesis no. 1 
2.3. Scenario no. 3 - concrete dam failure, hypothesis 2 - the rotation of the monolithic block of the spillway

It consists in turning the monolithic block of the spillway, to create a gap with a maximum span of $23 \mathrm{~m}$, while developing a breach in the earth dam on the left bank with a maximum opening of $16 \mathrm{~m}$ at the dam crest level (155.25 MaSL).

The hypotheses that characterize this scenario are:

the water level in Ezer reservoir corresponding to Q $0.1 \%$ is $154.72 \mathrm{MaSL}$, while the crest elevation is $155.25 \mathrm{MaSL}$;

the concrete dam failure occurs by turning around the shoulder of the right bank in an interval of 7 minutes;

the breach development in the earth dam occurs in 3 hours; the breach slope is 1:2.

It should be noted that in the discharge calculation through the breach area, the water level decrease from the reservoir with respect to time was taken into account.

The breach hydrograph was obtained using the Dambreak module of Mike 11 software. The discharge hydrograph resulted in scenario no. 3 is presented in Figure 5, and the flow has a maximum value of about $670 \mathrm{~m} 3 / \mathrm{s}$.

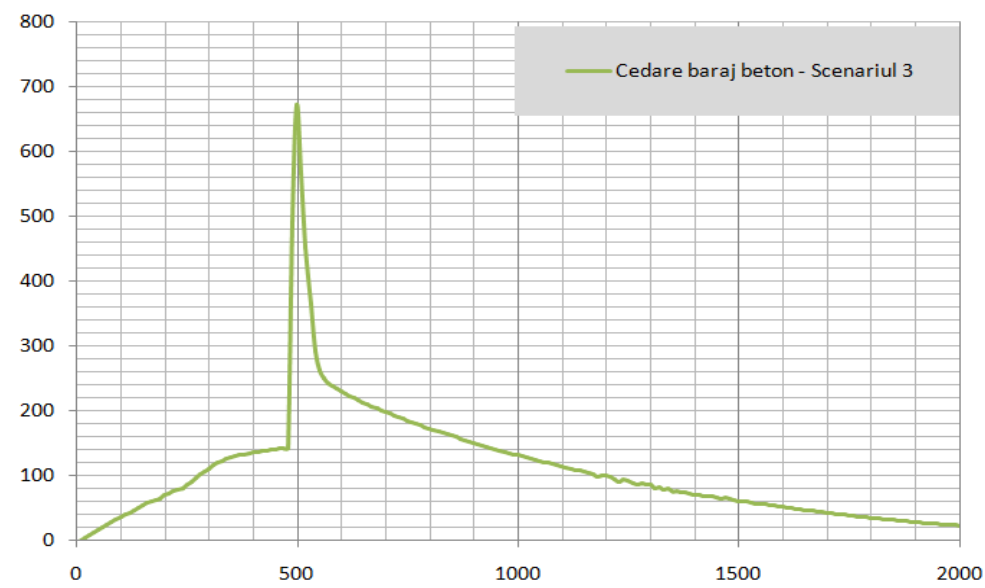

Fig. 5 - Flow hydrograph resulting from concrete dam failure - hypothesis no. 2

\section{Flood propagation}

The modelling process consists in the completion of three phases, namely [2]:

- the pre-processing phase - the realisation of the Digital Terrain Model, the set-up of the specific hydraulic model (introduction of the cross-sections, construction having hydraulic impact including bridges, hydraulic parameters and the boundary conditions;

- the calculation phase itself;

- the post-processing phase - the representation and interpretation phase of the results in various forms (hydrographs, water depth, velocity etc.).

\subsection{Digital terrain model}

The area in which the analysis was performed is located between Ezer dam section ( $\mathrm{km} \mathrm{218.209)}$ and downstream Dângeni gauge station (km 155.395). Mike 11 by DHI software was used for hydraulic modeling.

The hydraulic approach is 1-D type and the river stretch was divided into a number of 225 crosssections (Figure 6), meaning an average distance of about $580 \mathrm{~m}$ between them. 


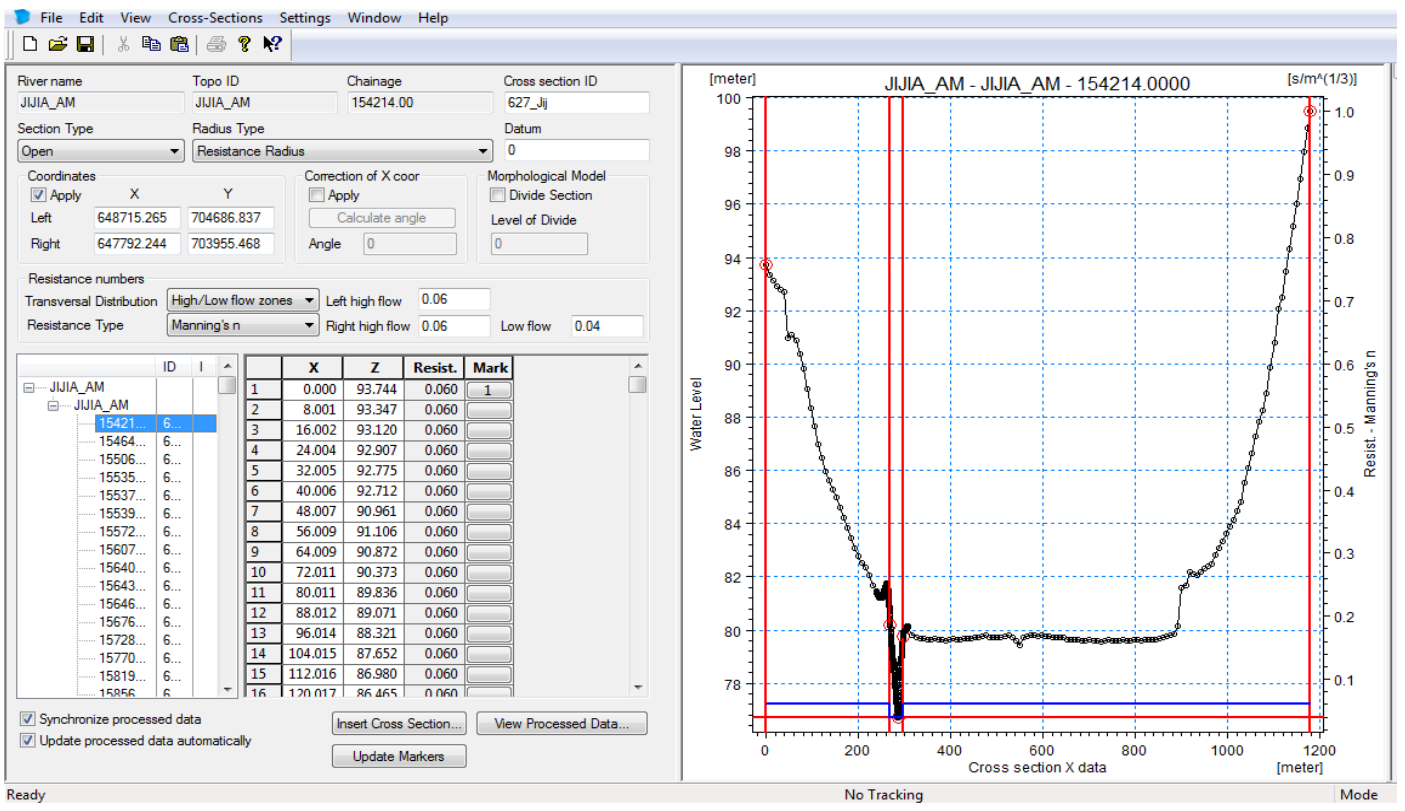

Figure 6. Usual cross section type introduced in the model

The boundary conditions in the model are:

- the breach wave in the analysed scenarios (S1, S2 and S3);

- the flood hydrographs for the tributaries of the Jijia river;

- the rating curve at Dângeni gauge station on the Jijia river (Fig. 7).

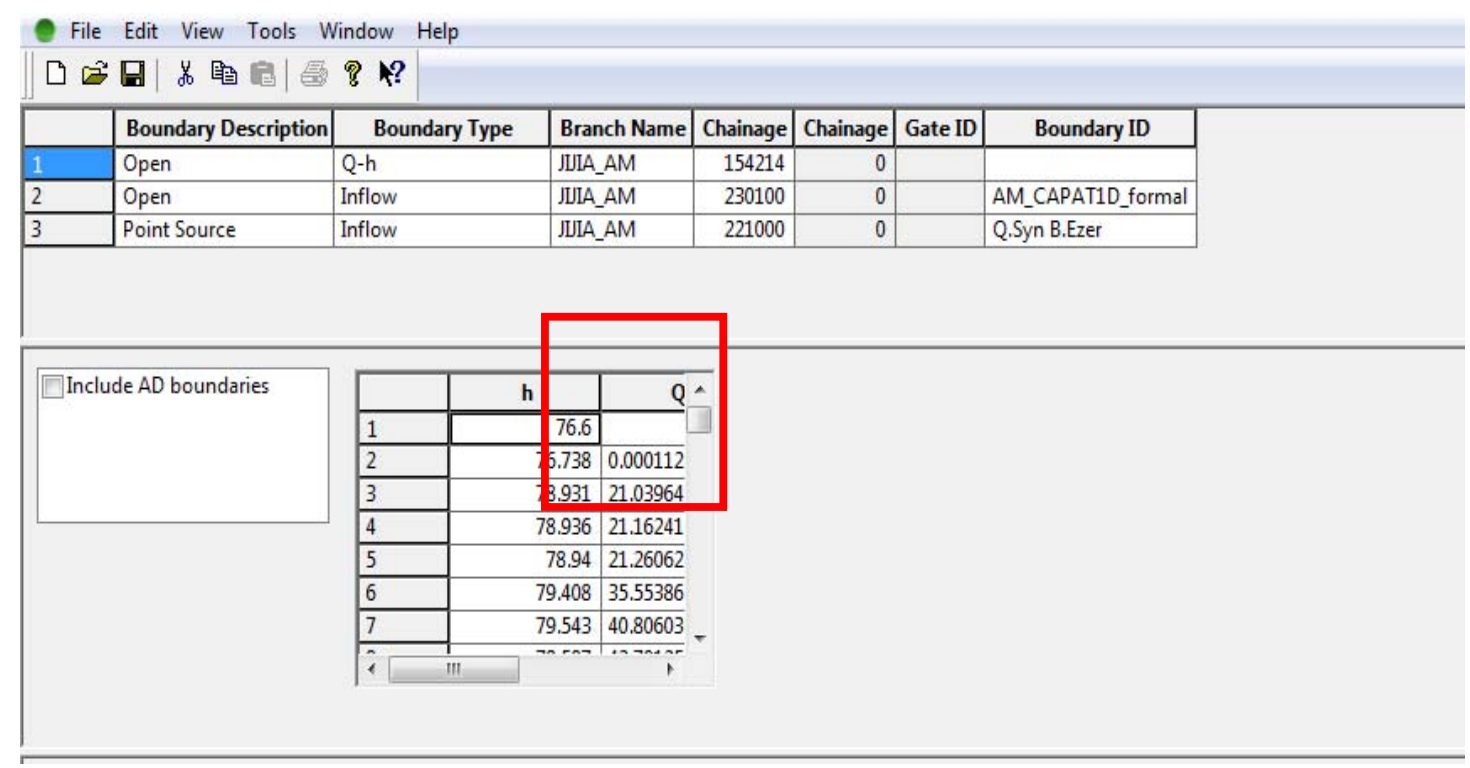

Fig. 7 - Entering the rating curve for the endpoint in the hydraulic model

For obtaining the contribution of the tributaries the rain corresponding to $0,1 \%$ probability of exceedance was considered throughout the Jijia river basin. This very severe hypothesis was considered in order to obtain the flood extent in one of the most dangerous scenario

\subsection{Deriving flooding maps}

To derive the flooding maps in GIS environment (based on ArcGIS 10.1) the following main steps were taken:

1. Creating the shape files;

2. Preparing the cross-sections that will be used to generate the free surface of the water; 
3. Generating the points containing water level values;

4. Generating the raster/screen with water level (for each subdomain of the patterned surface); the cell raster/ screen surface is $3 \mathrm{~m} \times 3 \mathrm{~m}$;

5. Getting the raster/ screen with the water depth;

6. Generating the polygon representing the flooding limit;

7. Correcting the polygon representing flooding limit;

8. Correcting the raster/screen with the water level and depth after deriving the final flooding limit.

\section{Chain effects due to Ezer dam failure}

\subsection{Stretch I: Ezer dam - Dorohoi town}

After only 30 minutes from the dam failure, the flood wave reaches the Dorohoi town; the flooded area is presented in Figure 8. The main infrastructures affected by the flood are:

- 4 bridges on the Jijia river, one of them being a railway bridge;

- about 7 streets flooded in a proportion of $70 \%$ and 4 streets about $20 \%$;

- about $280 \mathrm{~m}$ of county road, that connect Dorohoi town with Broscauti village, is flooded; the average water depth reaches about $1.5 \mathrm{~m}$;

- in the area numbered 3 from the figure, the average water depth reaches about $4.5 \mathrm{~m}$ at the bridge crossing the railway.

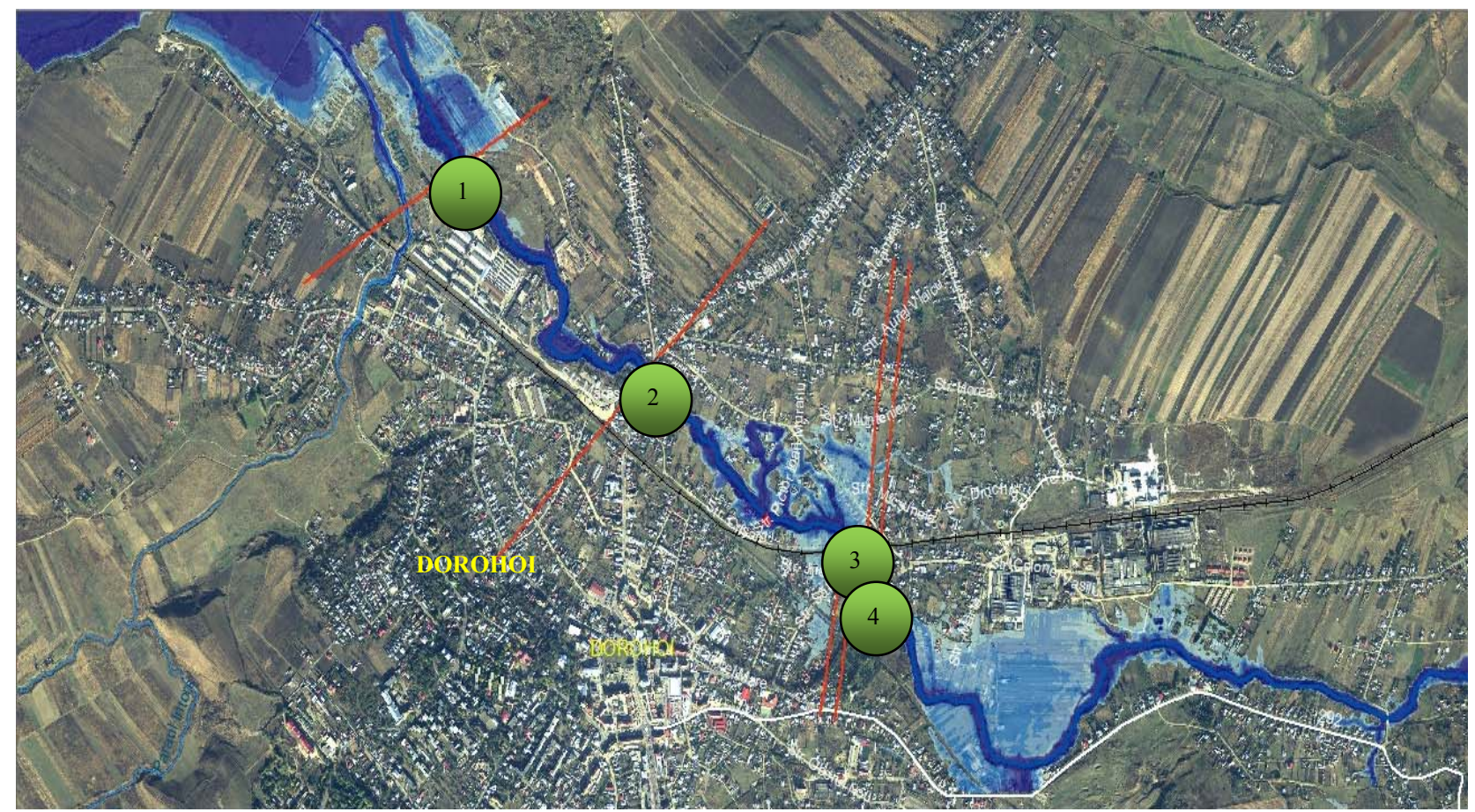

Fig. 8 - Flood propagation in Dorohoi town

\subsection{Stretch II: Dorohoi - Slobozia}

Because the bank level of the river on this stretch is higher than the maximum water level following the dam break the flood does not overtop the banks line (Figure no. 9). 


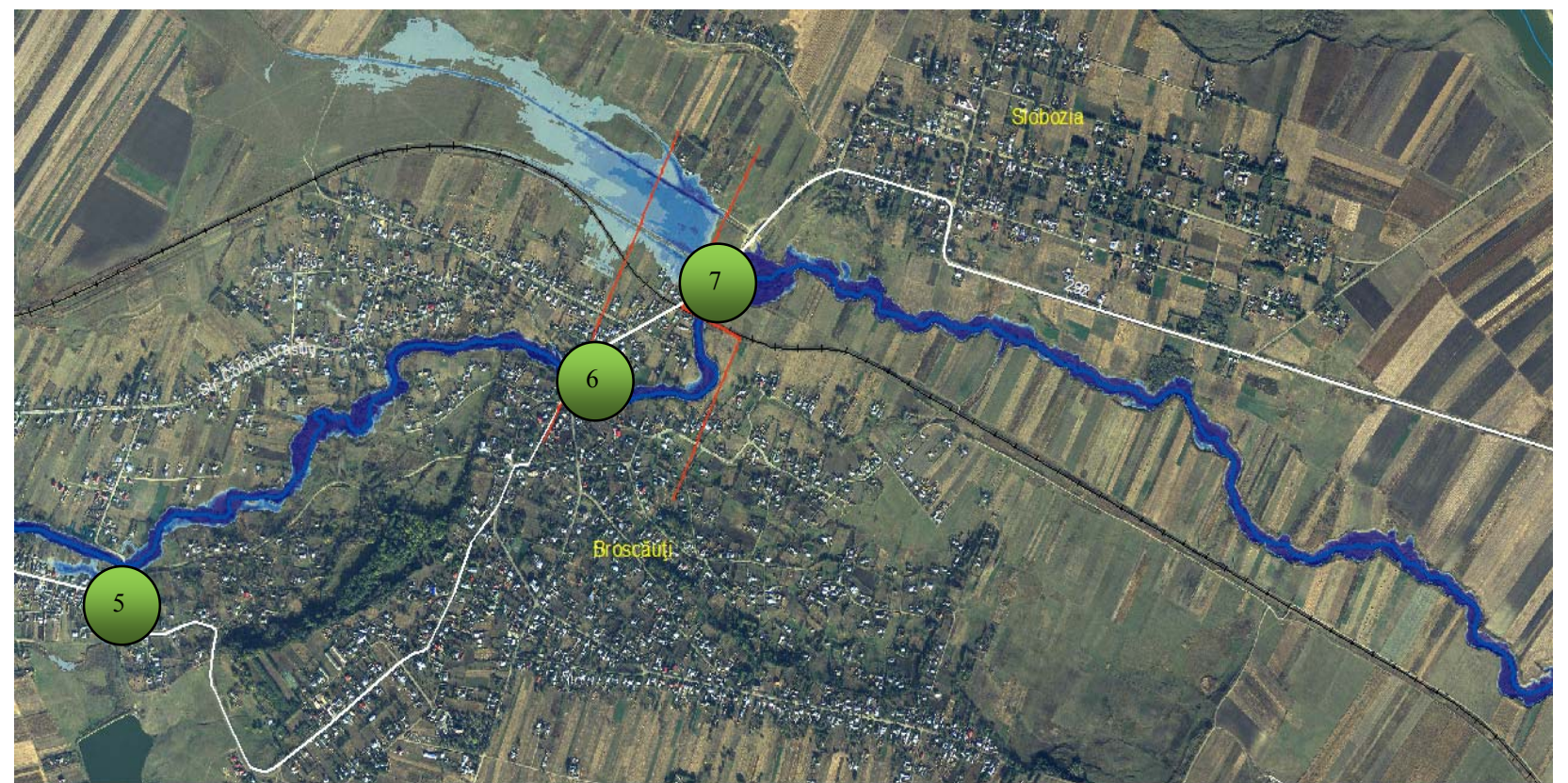

Fig. 9 - Flood propagation downstream the town of Dorohoi

Although on this stretch the houses are not exposed to flooding, some local infrastructures are affected by the flood, as it follows:

- Area no. 5 - the county road at the entrance in Broscauti village is flooded;

- Area no. 6 - the crossing bridge over Jijia River on the County Road 292 will probably collapse since the water depth in the bridge area reaches about $4 \mathrm{~m}$;

- Area no. 7 - the railway crossing bridge is also affected.

\subsection{Stretch III: Carasa - Mateieni}

The Mateieni village is flooded 2 hours and 30 minutes after the dam break (Fig. 10).

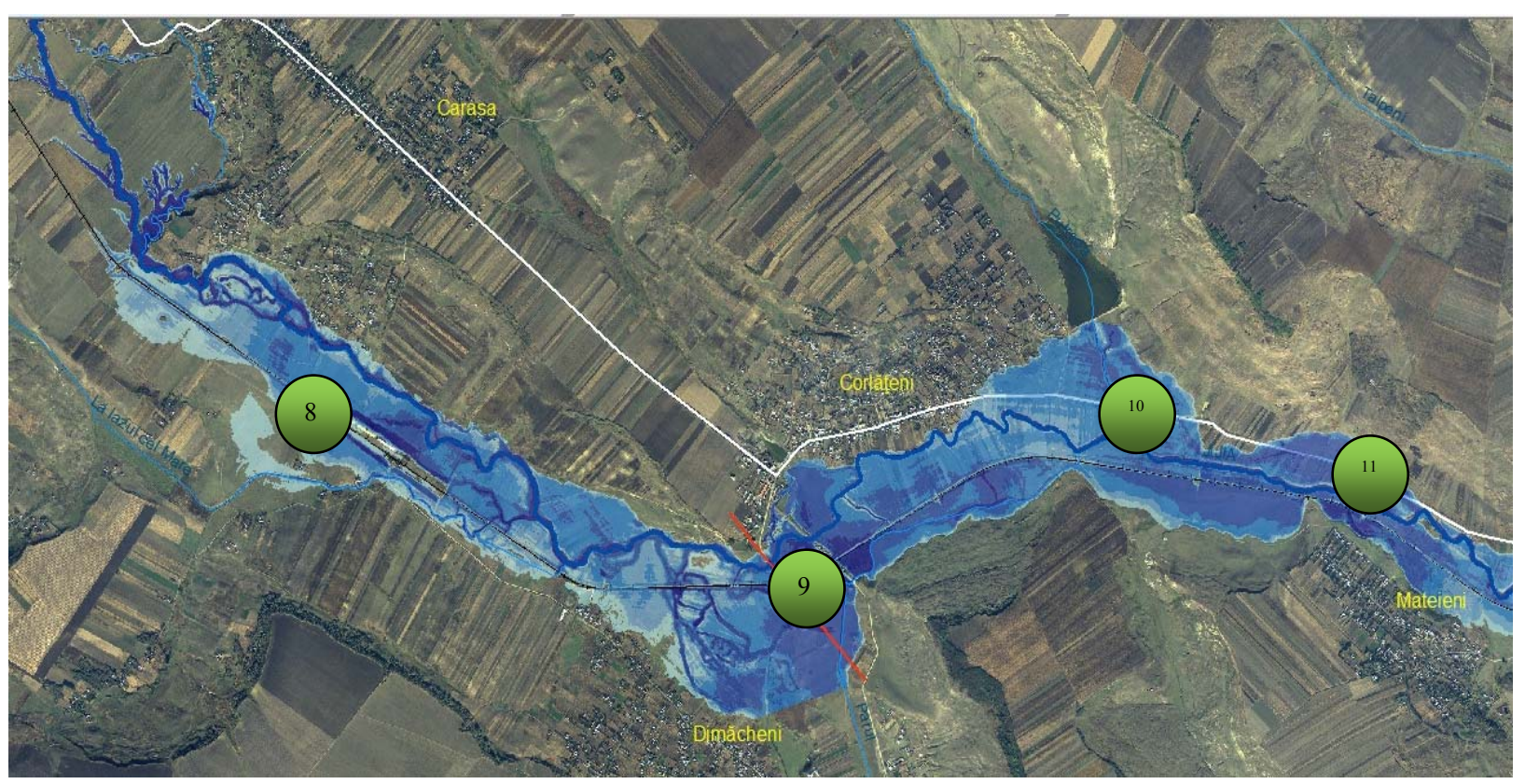

Fig. 10 - Flood propagation on the stretch Carasa - Mateieni

Similar to the stretch Broscauti - Slobozia, the floodplain is high and there are not houses exposed to flooding, but some local infrastructures are strongly affected by the flood, namely: 
- Area no. 8 - about $8.4 \mathrm{~km}$ of railway are flooded;

- Area no. 9 - about $450 \mathrm{~m}$ from the local road section connecting the villages Corlateni and Dimăcheni are affected; the average water depth is about $1.2 \mathrm{~m}$;

- Area no. 10 and 11 - about $2 \mathrm{~km}$ from the county road that connects Corlateni, Mateieni and Vlădeni villges are flooded; the average water depth is about $80 \mathrm{~cm}$.

\subsection{Stretch IV: Vlădeni - Călugăreni}

The flooding time of Vlădeni village is 3 hours and 50 minutes after the dam break, a little bit higher than for Călugăreni village (3 hours and 30 minutes), although the latter is located downstream.

The explanation is related to the bank level, which is flooded at lower discharges at Călugăreni village than in the case of Vlădeni village.

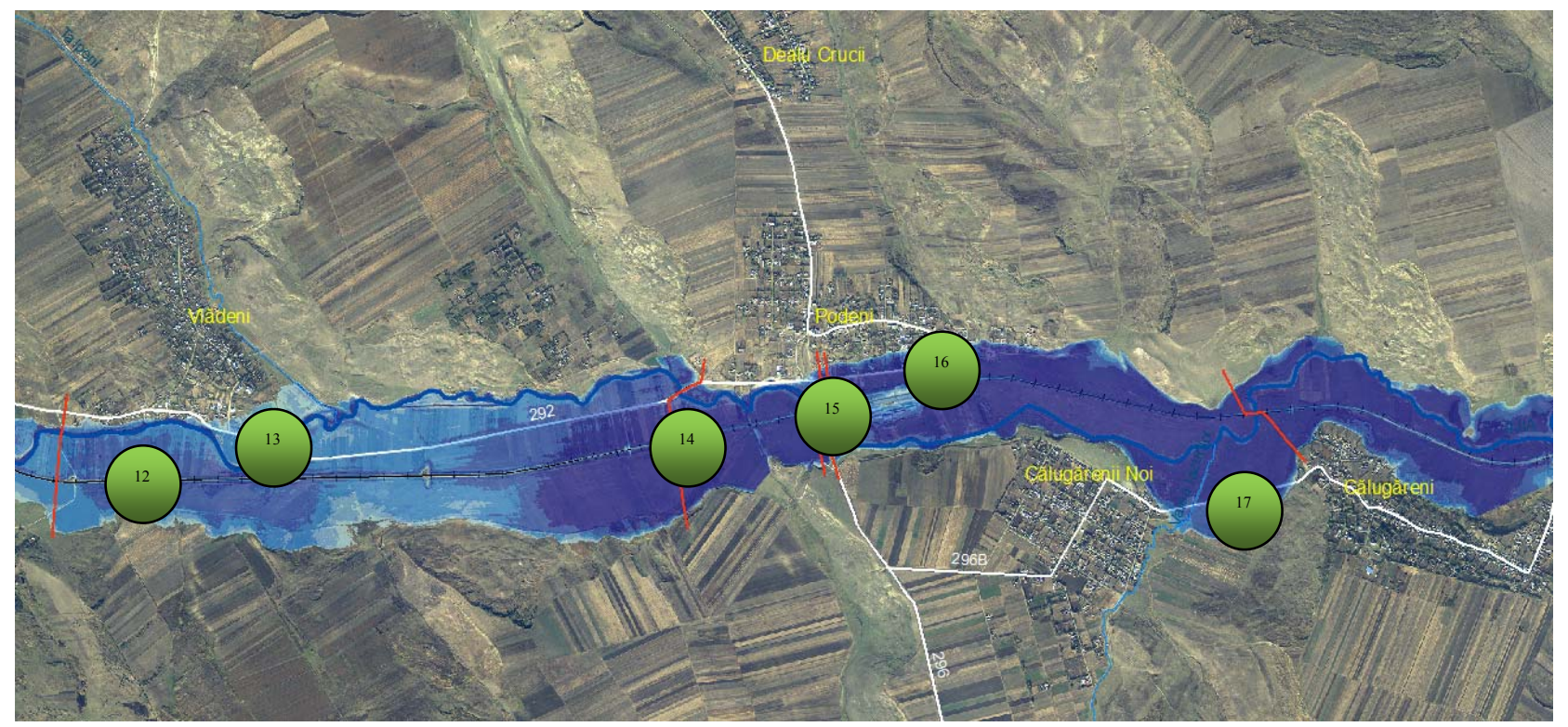

Fig. 11 - Flood propagation on the stretch Vlădeni - Călugăreni

Considering the $1 \%$ precipitation on the whole river basin, the discharges on Jijia River increase due to the tributaries, and more negative effects on local infrastructure are estimated, namely:

- Area no. 12 - about $7.8 \mathrm{~km}$ of rail are affected;

- Area no. 13, 14, 15 and 16 - about $3.2 \mathrm{~km}$ of county road that connects Podeni and Vlădeni villages are floodes; the average water depth is about $1.5 \mathrm{~m}$. More than that, a stretch of about $420 \mathrm{~m}$ from the county road that connects the villages Vlădeni and Podeni with Călugărenii Noi village is also affected by flood; the average water depth is 1.6 m. The connection to Călugărenii Noi village should made by the bridge from area no. 15 .

- Area no. 17 - about 680 m of local road linking Călugărenii Noi and Călugăreni villages are flooded; the average water depth on this section is $1.3 \mathrm{~m}$. 


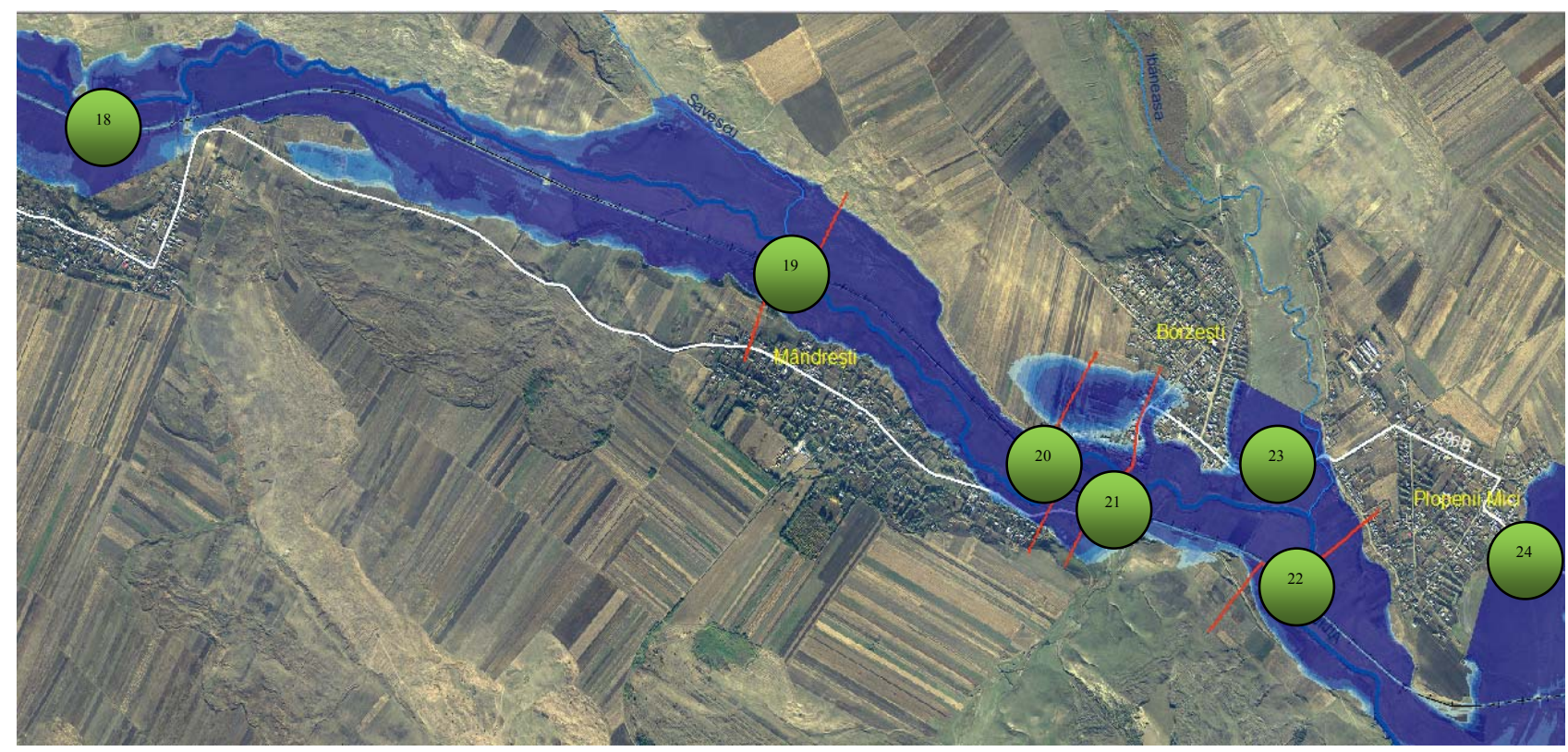

The dam failure combined with the rain $0.1 \%$, on the Jijia River basin has the following critical areas:

- Area no. 18, 19, 20, 21 and 22 - about $6.9 \mathrm{~km}$ of railroad are affected and 4 crossing bridges on the railway are exposed to flood; the water depth in the bridges area is about $3 \mathrm{~m}$;

- Area no. 23 and 24 - about $1.3 \mathrm{~km}$ of local road are flooded as well as the bridge linking Mândreşti and Borzeşti villages (area no. 21). The water depth in the vicinity of the bridge is about $3.5 \mathrm{~m}$.

\subsection{Stretch VI: Durnesti - Vicoleni}

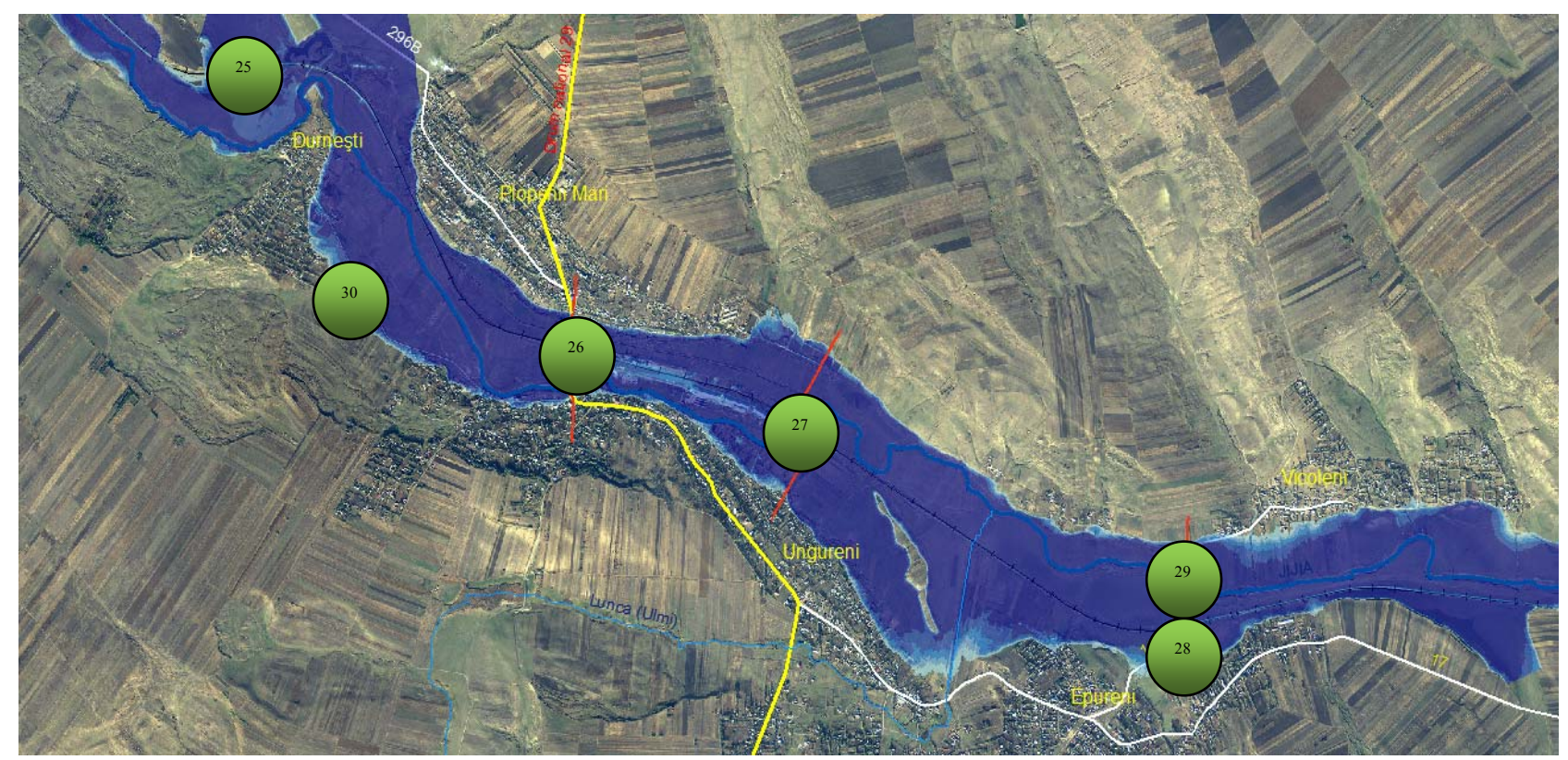

Fig.12 - Flood propagation on the stretch Durnesti - Vicoleni

As infrastructure affected by the dam failure the following critical areas are put into evidence:

- Area no. 25 and 27 - about $9 \mathrm{~km}$ of rail and one crossing bridge over the railway are exposed to the flood; the water depth in the bridges area is about $2.6 \mathrm{~m}$; 
- Area no. 26 - about $380 \mathrm{~m}$ from the national road linking Plopenii Mari with Botosani, as well as the crossing bridge linking Plopenii Mari with Ungureni are flooded; the water depth in the bridge area is about $2.7 \mathrm{~m}$;

- Area no. 28 and 29 - about 970 m from the local road linking the Epureni with Vicoleni and the crossing bridge over the Jijia river are affected; the water depth in the bridge area reaches about $3 \mathrm{~m}$;

- Area no. 30 - about $1.8 \mathrm{~km}$ of the local road linking Durnesti with Ungureni are flooded; the average water depth is about $2.6 \mathrm{~m}$.

\subsection{Stretch VII: Iacobeni - Dângeni}

Area no. 31, 32 and 33 - about $7.2 \mathrm{~km}$ of rail are affected and 2 crossing bridges over the railway are exposed to flood; the water depth in the bridges area is about $2 \mathrm{~m}$;

Area no. 34 - about 600 m of county road that connects Dangeni - Strahotin - DN 29 - Botosani are flooded; the average water depth is about $1.5 \mathrm{~m}$. At the same time, a stretch of about $420 \mathrm{~m}$ from the county road that connects the villages Vlădeni and Podeni with Călugărenii Noi, including the crossing bridge over Jijia river between Dangeni and Strahotin are affected; the water depth on this section is about $2.5 \mathrm{~m}$.

Area no. 35 - the railway station Dangeni is totally flooded as well as the railway to the endpoint of the model.

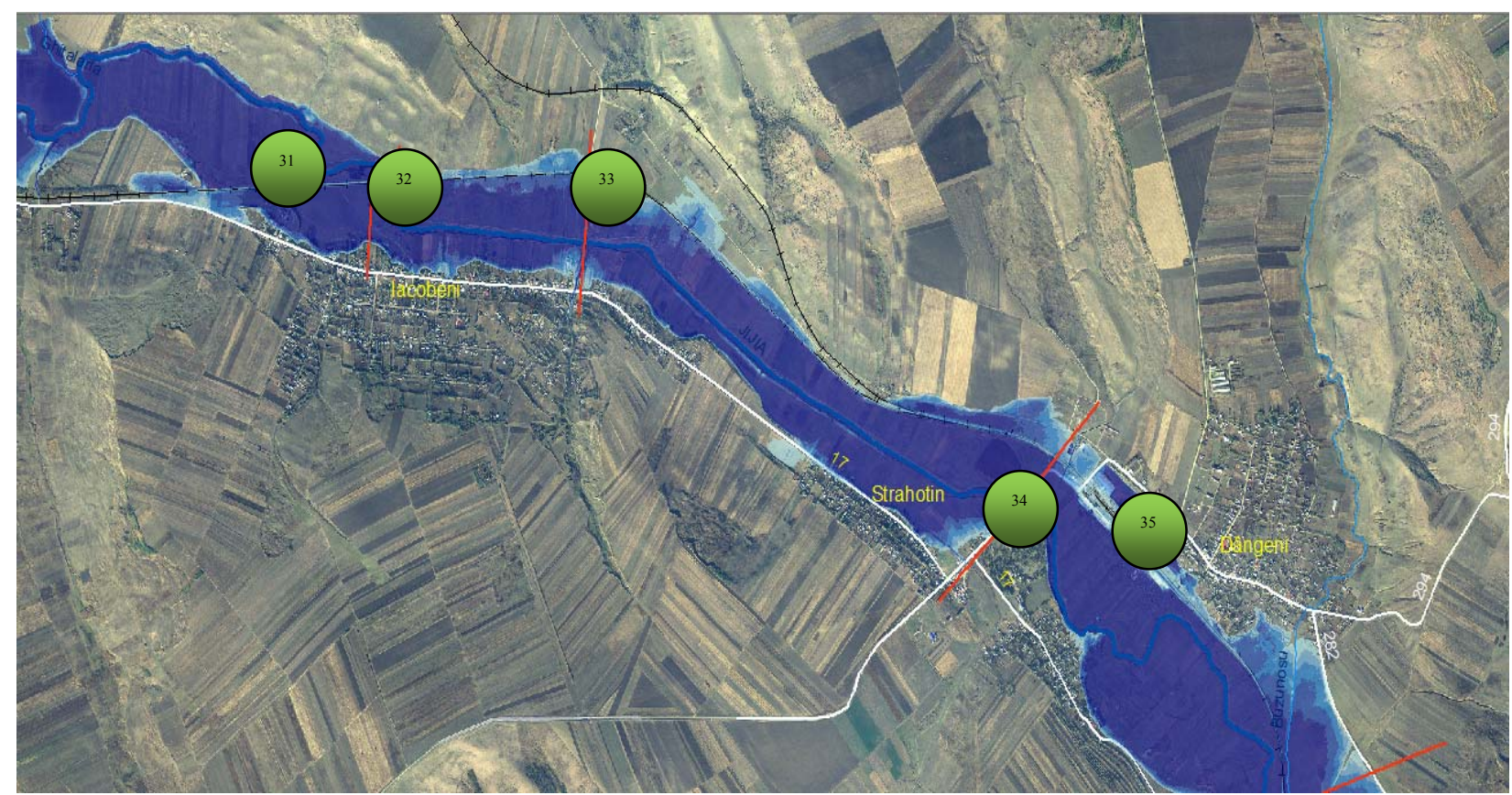

Fig. 13 - Flood propagation on the stretch Iacobeni - Dângeni

\section{The general scheme of interdependencies produced by the domino effect at the dam failure}

As described above, a number of facilities and services are jeopardized following the Ezer dam failure.

An accident of this kind is extremely dangerous for the citizens safety and social welfare; the domino effects it produces are immense and the range of disturbed regional infrastructure is very high [5], [7] (Figure 14). 


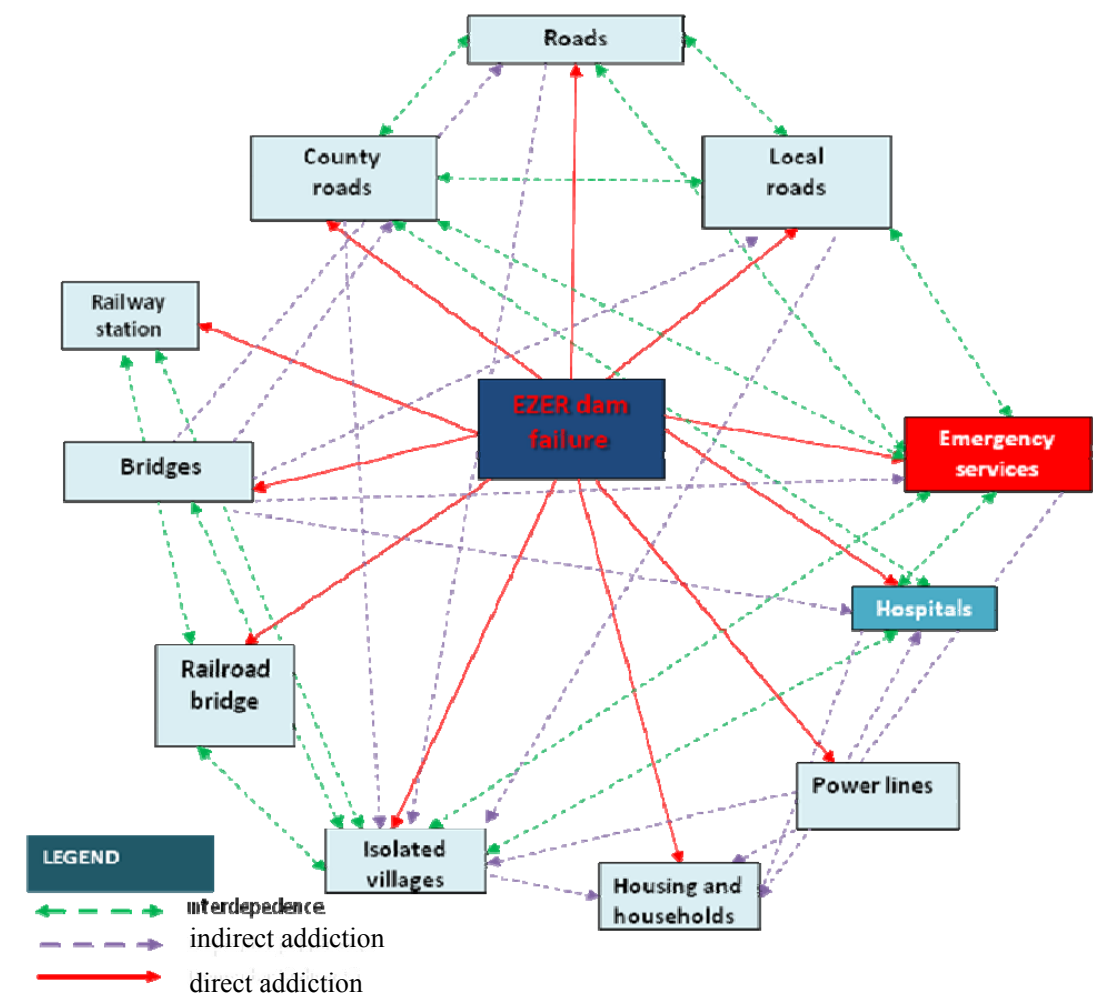

Fig. 14 - General scheme of interdependencies resulting from the dam failure

\section{Conclusions}

Following the above issues, the following conclusions can be clearly drawn:

The approach presenting the domino effects in terms of regional infrastructures protection and multi-risk evaluation can help create a regional communication and early warning mechanism in order to concentrate the financial efforts by the decision makers in areas of high vulnerability and creating the conditions for the development of a national mechanism for communication in crisis situations.

The analysis from the perspective of providing important services for social welfare and citizens' safety in the analyzed area outlined a comprehensive global framework of threats facing the community, but also the possible vulnerabilities of emergency services in case of intervention. A redeployment of forces and means, depending on the exposed area, or finding alternative interventions in such situations can therefore be possible.

Shaping a global framework for vulnerabilities, encompassing the entire spectrum of risks facilitates possible investment opportunity in infrastructure, environment, etc., in exposed areas. A cost/benefit analysis can be made when the whole framework of risks and problems facing people today is available.

\section{References}

[1] Vladimirescu I., (1978), Hidrologie, Ed. Didactică și Pedagogică, București.

[2] Stematiu D., Ionescu Şt., Altan Abdulamit, (2010), Siguranţa barajelor şi managementul riscului, Editura Conspress, Bucureşti.

[3] Drobot R., Amaftiesei R., Alexandrescu M.I., Chevereşan B., Modelarea efectului unui scenariu de cedare a barajului Lacul Morii, Hidrotehnica, vol. 52, nr. 12.

[4] Stănescu V.Al., Drobot R., (2002) Măsuri nestructurale de gestiune a inundaţiilor, Ed. HGA, Bucureşti.

[5] O’ Rourke T.D., (2007), Critical infrastructures, interdependencies, and Resilience, The Bridge.

[6] Strategia naţională privind protecţia infrastructurilor critice aprobată prin H.G. nr. 718/2011.

[7] Presentation of University of Notre Dame, Department of Engineering and Geological Sciences, Dam Failure Floods (https://www.uwgb.edu/dutchs/EnvGeol-PPT/Floods.ppt). 